\title{
Characteristics and Functional Specificity of Anti-Human BAT (Brain Associated Thymocyte Antigen) Serum
}

\author{
Chikao Morimoto, Tohru Abe, Takashi Toguchi and \\ Mrtsuo Homma \\ Department of Internal Medicine, Keio University School of \\ Medicine, Tokyo 160
}

\begin{abstract}
Morimoto, C., Aвe, T., Togdchi, T. and Homma, M. Characteristics and Functional Specificity of Anti-Human BAT (Brain Associated Thymocyte Antigen) Serum. Tohoku J. exp. Med., 1980, 130 (4), 321-334 - A rabbit antiserum to human fetal brain after multiple absorption reacted with $100 \%$ of thymocytes, $\mathbf{5 5} \%$ of peripheral blood lymphocytes and $\mathbf{9 0} \%$ of enriched $\mathrm{T}$ lymphocytes, but not significantly with B lymphocytes. Spontaneous SRBC rosette formation was inhibited by anti-BAT pretreatment, but EAC-rosette formation remained unaffected. The antiserum was itself highly stimulatory. However, cells treated with the antiserum and complement exhibited marked inhibition of responsiveness to Con A, little effect with PHA and no alteration with PWM. The MLC reaction was inhibited only when the responder cells were treated with the antiserum and complement. Treatment of sensitized lymphocytes with the antiserum and complement caused a dose-dependent suppression of blastogenic response to both PPD and n-DNA. No effect, however, was noted in MIF producing cells. Con A induced suppressor function of lymphocytes was abolished by treatment with the antiserum and complement. These results indicate that the anti-BAT serum obtained by us can be utilized for the isolation of $\mathrm{T}$ lymphocyte subsets. anti-human BAT; suppressor T lymphocyte; SLE; MLC
\end{abstract}

Two properties commonly used for identifying circulating $\mathrm{T}$ cells in man are their ability to form spontaneous rosettes with SRBC and their reactivity with anti- $T$ cell serum.

In mice the alloantigens, ly and theta, have been employed to distinguish between $\mathrm{T}$ cells and their subpopulations. Theta antigen cross-reacts with antigen from brain cells. Heterologous antibrain serum has thus been utilized as a substitute for antitheta serum.

Received for publication, April 9, 1979.

Correspondence to C. Morimoto; Department of Internal Medicine, Keio University School of Medicine, 35 Shinanomachi, Shinjuku-ku, Tokyo 160, Japan.

Abbreviations: BAT, brain associated thymocyte antigen; Con A, concanavalin A; EAC, sheep erythrocyte-antibody-complement complex; E-RFC, erythrocyte rosette forming cells; FCS, fetal calf serum; MLC, mixed lymphocyte culture; MIF, migration inhibitory factors; n-DNA, native DNA; PBS, phosphate buffered saline; PHA-M, phytohemagglutinin M; PPD, purified protein derivative; PWM, pokeweed mitogen; SLE, systemic lupus erythematosus; SRBC, sheep red blood cells. 
Antisera raised against brain tissue contain antibodies to species and nonspecies specific antigens. Such antisera, termed "anti-brain associated thymocyte antigens" (anti-BA'T), are cytotoxic to mouse thymocytes and inhibit both the primary immune response to SRBC in vitro (Barker et al. 1973) and the graft vs. host reaction (Golub 1971).

The production of anti-human brain serum by immunizing rabbits with human brain, however, has remained controversial. Kongshaven et al. (1974) were unable to produce significant lymphocytotoxic antibody by immunizing rabbits with human frontal lobe. Recently, however, Brown and Greaves (1974) succeeded in obtaining $\mathrm{T}$ cell specific antisera by the same method. Brouet and Toben (1976) have also showed that rabbit antiserum to human fetal brain reacted with a subpopulation of normal human $\mathrm{T}$ cells after suitable absorption.

In the present study, we examined the effect of anti-human BAT serum on the immunological reactivity of lymphocytes.

\section{Materials and Methods}

Preparation of anti-human brain serum in rabbits

The brain of a human fetus at 28 weeks of gestation was removed and homogenized with 0.1 M phosphate buffered saline (PBS), pH 7.2. The homogenate was centrifuged at $3,000 \mathrm{rpm}$ for $10 \mathrm{~min}$. The supernatant was then recentrifuged at $10,000 \mathrm{rpm}$ for 30 min. The sediment was suspended in $18 \mathrm{ml}$ of PBS. Three $\mathrm{ml}$ of the brain homogenate were mixed with an equal amount of Freund's complete adjuvant (Difco Lab., Detroit, Mich.) and injected into the foot pads of rabbits. Two weeks later, a second injection of the homogenate was made into the neck muscle, followed by a booster injection after 2 weeks. Blood was drawn 7 days after the last immunization.

\section{Absorption of antiserum}

The antiserum was decomplemented by heating at $56^{\circ} \mathrm{C}$ for $30 \mathrm{~min}$, and absorption with $\mathrm{AB}$ human erythrocytes at $0^{\circ} \mathrm{C}$ for $60 \mathrm{~min}$ was repeated 3 times. Two further absorptions were performed with $\mathrm{B}$ cell lines (NC-37, Daudi and Raji cells). Absorption was carried out with $2 \times 10^{\circ}$ cells per $\mathrm{ml}$ of anti-BAT serum at $0^{\circ} \mathrm{C}$ for $60 \mathrm{~min}$. Finally, the antiserum was passed through a human immunoglobulin affinity column coupled to activated Sepharose $4 B$.

\section{Cell lines}

Molt cells and three $\mathbf{B}$ cell lines were used for the absorptions. Mollt cells, $\mathbf{T}$ cell lines, were obtained from the National Cancer Center, NC-37 from Tsukuba University, Daudi from the Department of Pathology, School of Medicine, Keio University, and Raji from Toho University. They were maintained at $37^{\circ} \mathrm{C}$ in a suspension culture using RPMI-1640 supplemented with 10\% heat-inactivated fetal calf serum (Grand Island Biological Co., Grand Island, N.Y.).

\section{Cytotoxicity tests}

Cytotoxicity tests of the antiserum were made by a 2 -stage cytotoxicity assay using 0.2 Nygrosine. One tenth $\mathrm{ml}$ of cell suspension containing $1 \times 10^{8} / \mathrm{ml}$ was mixed with $0.1 \mathrm{ml}$ of a variously diluted antiserum. The mixture was kept in ice for $40 \mathrm{~min}$ with shaking every 10 min. After incubation, the cell suspension was centrifuged at $1200 \mathrm{rpm}$ for $5 \mathrm{~min}$ and the supernatant was removed. The cells were washed with FCS free medium and then $0.2 \mathrm{ml}$ of rabbit complement was added, and the mixture was incubated at $37^{\circ} \mathrm{C}$ for $50 \mathrm{~min}$. The 
cell suspension was centrifuged at $1,200 \mathrm{rpm}$ for $5 \mathrm{~min}$, the supernatant removed and $0.2 \mathrm{ml}$ of $0.2 \%$ Nygrosine added. The numbers of viable and dead cells were counted. The viability was calculated by dividing the number of viable cells by the total cells counted and multiplying by 100 . Tests for the presence of cytotoxic substances in this cytotoxicity test unrelated to antibodies, were made with normal rabbit serum and complement control. The cell control experiment was performed by measuring the cytotoxicity to cells without the addition of either complement or antibody.

\section{Separation of peripheral blood lymphocytes}

Lymphocytes were separated from the peripheral blood by centrifugation on a FicollHypaque gradient. The purity of the lymphocytes exceeded $97 \%$. No attempts were made to deplete the mononuclear cell population of adherent or phagocytic cells.

\section{Preparation of $S R B C$ rosettes $(E-R F C)$}

Rosette formation was performed according to the method of Jondal et al. (1972). Lymphocyte suspension $\left(2 \times 10^{6} / \mathrm{ml}\right)$ was added to an equal volume of sheep red blood cells (SRBC; $1 \times 10^{8} / \mathrm{ml}$ ) and incubated at $37^{\circ} \mathrm{C}$ for $15 \mathrm{~min}$. The mixture was then centrifuged at $700 \mathrm{rpm}$ for $5 \mathrm{~min}$ and allowed to stand for $1 \mathrm{hr}$ at $4^{\circ} \mathrm{C}$. The cell pellet was gently resuspended and examined for rosette formation.

\section{Identification of $B$ (EAC-rosette) lymphocytes}

This was performed on sensitized SBRC with antibody and C5 deficient AKR mouse serum as a source of complement. Sensitization was effected by incubating equal volumes of a $5 \%$ suspension of washed SRBC and a 1:400 dilution of amboceptor in saline at $37^{\circ} \mathrm{C}$ for $15 \mathrm{~min}$. The sensitized cells were washed, and a $5 \%$ suspension was prepared in saline (EA). Equal volumes of $\mathbf{E A}$ and mouse complement were then incubated at $37^{\circ} \mathrm{C}$ for $15 \mathrm{~min}$ (EAC). For the identification of $\mathrm{B}$ lymphocytes, $0.3 \mathrm{ml}$ of lymphocyte suspension was added to an equal volume of $\mathrm{EAC}$ and incubated at $37^{\circ} \mathrm{C}$ for $1 \mathrm{hr}$, followed by standing for another $1 \mathrm{hr}$ at room temperature. These cells were positively identified by the presence of $\mathrm{Ig}$ receptor on their membranes with $\mathrm{F}(\mathrm{ab})_{2}$ fragment of fluorescent antibody. An average of $90 \%$ of the cells was stained.

\section{Preparation of purified $T$ and $B$ lymphocytes from peripheral blood lymphocytes}

After formation of E-RFC by peripheral blood lymphocytes, celll suspensions containing rosettes were again layered over the Ficoll-Hypaque mixture and centrifuged at 2150 rpm for $40 \mathrm{~min}$ at room temperature. The E-RFC sedimented at the bottom. The cells at the interface of the Ficoll-Hypaque mixture were termed E-RFC depleted cells. The sedimented cells were treated with Tris-ammonium chloride buffer to lyse erythrocytes. E-RFC were considered to be T lymphocytes, and when tested by indirect immunofluorescence, over $95 \%$ of the cells were confirmed to be non-stained. The reamining E-RFC depleted cells were positively identified by the presence of $\mathrm{Ig}$ receptor on their membranes with $\mathrm{F}(\mathrm{ab})_{2}$ fragment of fluorescent antibody. An average of $90 \%$ of the cells was stained.

\section{Mitogen response}

The response of lymphocytes to non-specific mitogens was assessed by using phytohemagglutinin-M (PHA-M; Difco Lab., Detroit, Mich.), Concanavalin A (Con A; Sigma Chemical Co., St. Louis, Mo.) and Pokeweed mitogen (PWM; Grand Island Biological Co., Grand Island, N.Y.). The concentration of these mitogens was determined in preliminary experiments. Five $\times 10^{5}$ lymphocytes were cultured in $3 \mathrm{ml}$ of RPMI-1640 with $10 \%$ fetal calf serum (FCS) (Grand Island Biological Co., Grand Island, N.Y.) in the presence or absence of the mitogens. Lymphocytes were cultured for 3 days in the case of PHA-M and Con A, and 5 days in PWM stimulation. Two hr before harvest, $50 \mu l$ of medium containing $3 \mu \mathrm{Ci}$ of tritiated thymidine ( $N$ ew England Nuclear, North Billerica, Ma.; sp. act. $9.3 \mathrm{mCi} / \mathrm{ml}$ ) was added to each culture tube to estimate DNA synthesis. The 
radioactivity of the TCA precipitate was determined with a Packard Scintillation Counter (Stanford, Calif.) in triplicate.

\section{Mixed lymphocyte culture}

Mixed lymphocyte reactions were performed in triplicate. Stimulator cells were treated with $25 \mu \mathrm{g} / \mathrm{ml}$ of Mitomycin $\mathrm{C}$ at $37^{\circ} \mathrm{C}$ for $30 \mathrm{~min}$ to inhibit mitosis. They were washed 3 times in RPMI-1640. Five $\times 10^{5}$ cells/tube were used as stimulator cells and an equal number as responder cells. The cells were incubated for 5 days at $37^{\circ} \mathrm{C}$ in $5 \% \mathrm{CO}_{2}: 95 \%$ air pulsed with $3 \mu \mathrm{Ci}$ of ${ }^{3} \mathrm{H}$-thymidine per tube $2 \mathrm{hr}$ before harvest.

\section{Production of MIF and the macrophage inhibitory (MI) test}

The production of MIF was based on the method of Thor et al. (1968). Lymphocytes were adjusted to $1 \times 10^{8}$ cells for culture. In each experiment, the cells to be tested were divided into 2 culture tubes with or without PPD or n-DNA as an antigen in PRMI1640 containing $10 \%$ FCS. The culture tubes were incubated for 3 days. At the end of this period, the supernatant was removed by centrifugation at $2000 \mathrm{rpm}$ for $10 \mathrm{~min}$ followed by ultracentrifugation to eliminate antigen-antibody complexes. The concentration of PPD and n-DNA as an antigen was $10 \mu \mathrm{g} / \mathrm{ml}$. To detect possible non-specific macrophage inhibition due to PPD or n-DNA, additional controls of medium alone and medium with PPD or n-DNA were prepared in each experiment and processed in the same way as the supernatant. The test supernatant and control media were assayed on normal guinea pig peritoneal exudate cells in capillary tubes by the method of David and Schlossman (1968).

\section{Measurement of Ig synthesis in vitro}

Lymphocytes $\left(1 \times 10^{6}\right)$ were cultured in $3 \mathrm{ml}$ of RPMI-1640 with $10 \%$ FCS for 5 days. The cultured cells were washed 3 times with Hanks' balanced salt solution (HBSS) (Grand Island Biological Co., Grand Island, N.Y.). Culture was then continued for another $24 \mathrm{hr}$ in $2 \mathrm{ml}$ of essential special medium lacking leucine with $5 \%$ fresh $\mathrm{AB}$ serum and $5 \mu \mathrm{Ci}{ }^{14} \mathrm{C}$-leucine (New England Nuclear, North Billerica, Ma.). Immunoglobulin synthesis was measured by an immune coprecipitation method as described previously (Morimoto et al. 1977).

\section{Results}

\section{Cytotoxicity against Molt cells}

The complement-dependent cytotoxic effect of rabbit antiserum against human fetal brain on Molt cells and Daudi cells was tested with serially diluted antiserum. As shown in Fig. 1, the antiserum killed $100 \%$ of Molt cells at a serum dilution of between $1: 2$ and 1:64. One absorption of antiserum $(1 \mathrm{ml})$ with $1 \times 10^{8}$ Molt cells resulted in a reduction of cytotoxicity to $30 \%$ at a $1: 32$ dilution. The antiserum was slightly cytotoxic to Daudi cells at a $1: 2$ to $1: 8$ dilution, but no such effect was observed with a $1: 32$ dilution.

\section{Cytotoxicity against thymocytes and peripheral blood lymphocytes}

Since the Molt cell has an antigenic determinant shared with thymocytes, we were interested in determining the cytotoxicity against thymocytes and peripheral blood lymphocytes by employing this hetero-antiserum to brain. Thymocytes were obtained from thymus tissue which was removed incidentally from young children (2.5-6 years old) undergoing open heart surgery.

The cytotoxicity against enriched $\mathrm{T}$ and $\mathrm{B}$ lymphocytes was also examined. 


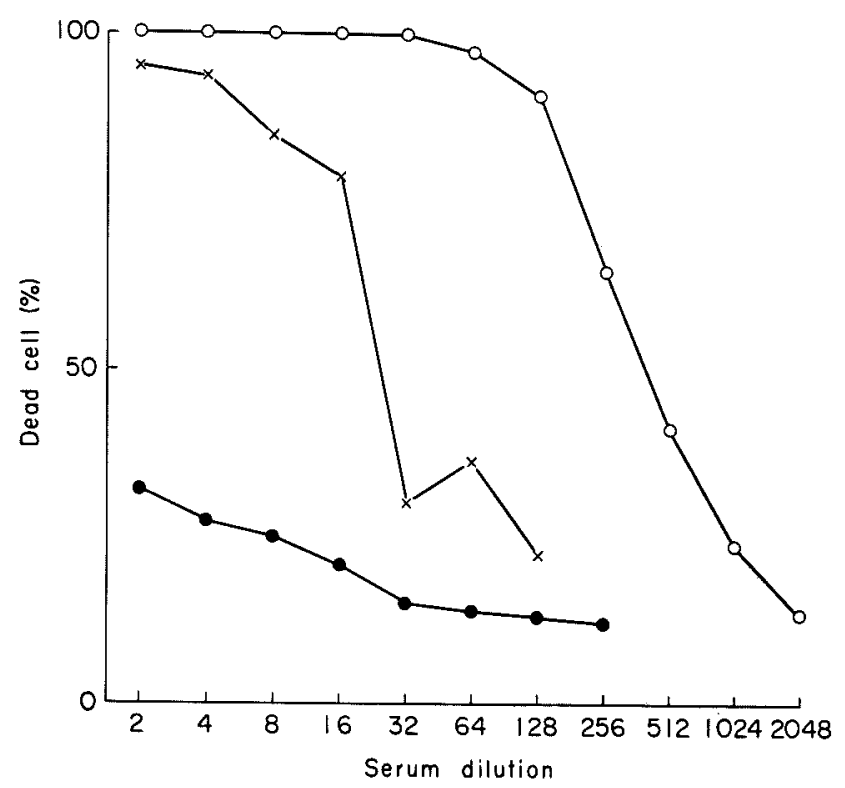

Fig. 1. Cytotoxicity of rabbit antiserum against human fetal brain to the established cell lines.

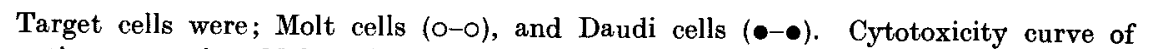
antiserum against Molt cells after absorption with $1 \times 10^{8}$ Molt cells $(x-x)$.

As shown in Fig. 2, 100\% of thymocytes (open circles) were killed by the antiserum between dilutions of $1: 2$ and $1: 4$. The antiserum killed about $55 \%$ of peripheral blood lymphocytes (solid circles) at a 1:2 dilution, and a plateau of cytotoxicity was observed at dilutions of $1: 32$ to $1: 128$.

Almost $90 \%$ of enriched T lymphocytes were killed by the antiserum at a $1: 4$ dilution. The cytotoxic activity decreased rapidly at higher dilutions of antiserum forming a plateau at dilutions of $1: 32$ to $1: 128$. The antiserum showed slight cytotoxic activity against enriched $B$ lymphocytes at dilutions of $1: 4$ to $1: 8$, but no effect was noted thereafter.

\section{Effect of anti-BAT serum on spontaneous $S R B C$ rosette formation}

The specificity of anti-BAT serum for T lymphocytes was determined from the ability of the anti-BAT serum to inhibit the formation of either spontaneous E-rosettes or EAC-rosettes. When peripheral blood lymphocytes were incubated with antiBAT serum, before the addition of SRBC or EAC, rosette formation was inhibited at dilutions of $1: 100-1: 200$ without addition of complement. In contrast, anti-BAT serum pretreatment did not inhibit EAC rosette formation as well as normal rabbit serum pretreatment (Fig. 3).

\section{Treatment of peripheral blood lymphocytes with anti-BAT serum}

Cytotoxicity tests against thymocytes and enriched $\mathrm{T}$ lymphocytes proved 


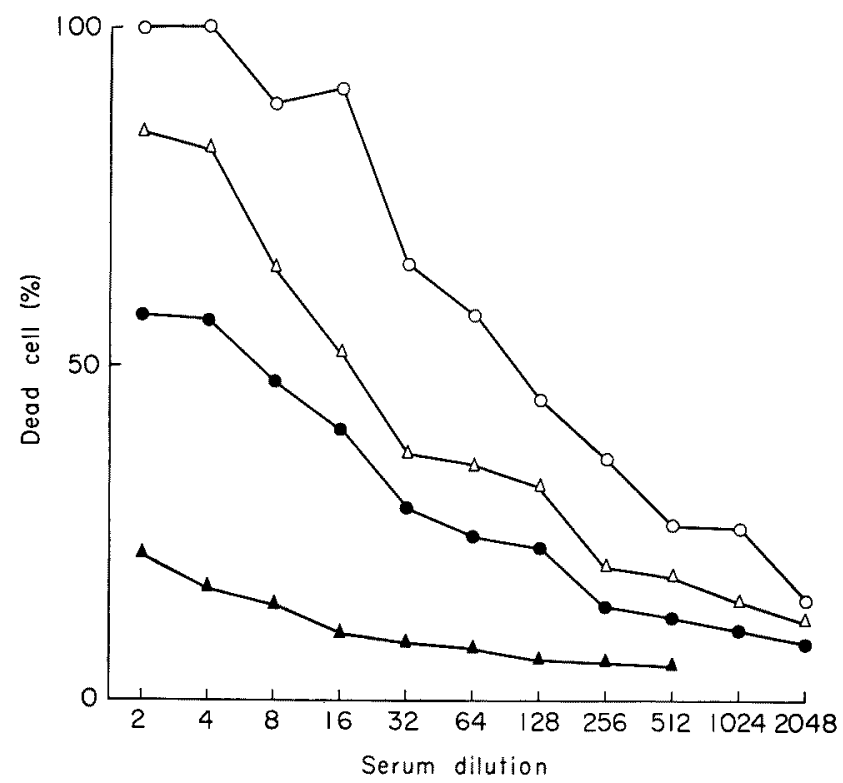

Fig. 2. Cytotoxicity of anti-BAT serum was examined against thymocytes (0-O), unseparated peripheral blood lymphocytes $(\bullet-\bullet)$, enriched $T(\Delta-\Delta)$ and enriched $B(\Delta-\Delta)$ lymphocytes. Thymocytes were obtained from thymus tissue incidentally removed from young children (2.5-6 years old) underoging open heart surgery. All data are mean of 4 individuals.

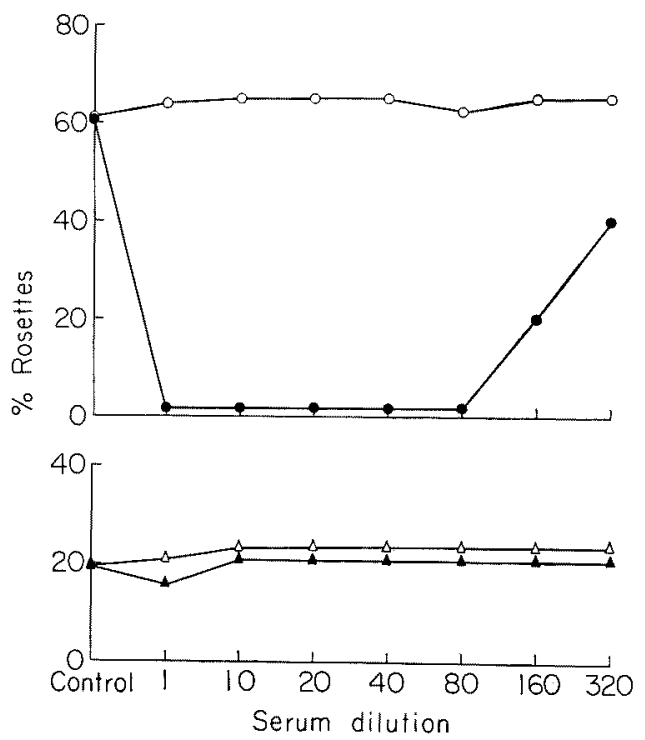

Fig. 3. Effect of anti-BAT serum on rosette formation was determined. The effect of anti-BAT serum pretreatment on spontaneous SRBC rosette formation (upper) and EAC rosette formation (lower) with lymphocytes in the absence of complement. Solid symbols indicate the pretreatment with anti-BAT serum, and open symbols that with normal rabbit serum. 
that our anti-BAT serum had $\mathrm{T}$ cell specificity after multiple absorption with established B cell lines. Examinations were made to test its functional ability to act as a specific T lymphocyte mitogen. Peripheral blood lymphocytes were tested with various dilutions of anti-BAT serum or anti-BAT serum and complement. The lymphocytes were incubated for $72 \mathrm{hr}$ after washing 3 times with PBS and pulsed with ${ }^{3} \mathrm{H}$-thymidine. As shown in Fig. 4, treatment with anti-BAT serum alone acted as a potent mitogen, while lymphocytes treated with anti-BAT serum and rabbit complement did not exhibit the response at any dilution.

Changes of mitogenic response by anti-BAT serum and complement

The effect of anti-BAT serum and complement on the activity of lymphocytes to respond to various non-specific mitogens was examined. Four experiments were performed in which lymphocytes were treated with the indicated cytotoxic titer of anti-BAT serum and complement. Viable lymphocytes collected with an FCS gradient were incubated with non-specific mitogens. As shown in Table 1, the ability of the anti-BAT serum treated lymphocytes to respond to Con A was markedly inhibited even at a low concentration of anti-BAT serum. The response of lymphocytes to $\mathrm{PHA}-\mathrm{M}$ was slightly affected at a higher concentration,

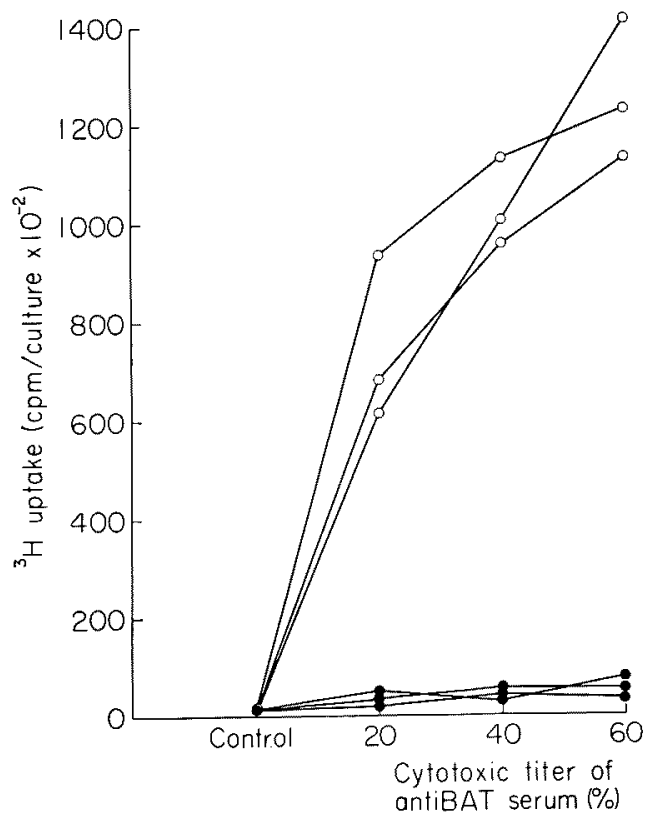

Fig. 4. Treatment of lymphocytes with anti-BAT serum. Uptake of ${ }^{3} \mathrm{H}$ thymidine by lymphocytes after treatment with various concentrations of anti-BAT serum alone (O-O) or with complement $(\bullet-\bullet)$.

Cytotoxic titer of anti-BAT serum was determined by preliminarily determined cytotoxic curve. Sixty percent killing corresponds to a level of anti-BAT serum between $1: 2$ to $1: 8,40 \%$ between $1: 16$ to $1: 64$ and $20 \%$ between $1: 256$ to $1: 512$ dilution. As control, lymphocytes were treated by normal rabbit serum and complement. 
TABLE 1. Anti-BAT serum treatment and mitogen response

\begin{tabular}{|c|c|c|c|c|c|c|c|}
\hline \multirow{4}{*}{$\begin{array}{l}\text { Exp. } \\
\text { No. }\end{array}$} & \multirow{4}{*}{$\begin{array}{l}\text { Cytotoxic } \\
\text { titer }\end{array}$} & \multicolumn{6}{|c|}{$\left({ }^{3} \mathrm{H}\right) \mathrm{TdR}$ incorporation in response to mitogens } \\
\hline & & \multirow{2}{*}{\multicolumn{2}{|c|}{ PHA }} & \multirow{2}{*}{\multicolumn{2}{|c|}{$\begin{array}{l}\text { Stimulated with } \\
\text { ConA }\end{array}$}} & \multirow{2}{*}{\multicolumn{2}{|c|}{ PWM }} \\
\hline & & & & & & & \\
\hline & & $c p m$ & $\%$ Supp. & $c p m$ & $\%$ Supp. & $c p m$ & $\%$ Supp. \\
\hline \multirow[t]{4}{*}{+} & $60 \%$ & $46026 \pm 4578$ & 23.9 & $20193 \pm 240$ & 67.7 & $19260 \pm 753$ & -14.3 \\
\hline & $40 \%$ & $51590 \pm 944$ & 14.8 & $26992 \pm 840$ & 56.9 & $16708 \pm 589$ & 0.9 \\
\hline & $20 \%$ & $56019 \pm 501$ & 7.4 & $38151 \pm 811$ & 39.0 & $14364 \pm 590$ & 14.8 \\
\hline & Cont. & $60523 \pm 3123$ & - & $62585 \pm 1630$ & & $16851 \pm 494$ & - \\
\hline \multirow[t]{4}{*}{2} & $60 \%$ & $52387 \pm 3292$ & 11.8 & $17060 \pm 266$ & 63.5 & $29395 \pm 728$ & -6.9 \\
\hline & $40 \%$ & $46679 \pm 538$ & 21.4 & $26435 \pm 785$ & 43.4 & $26529 \pm 867$ & 3.5 \\
\hline & $20 \%$ & $54352 \pm 1254$ & 11.8 & $25727 \pm 241$ & 45.0 & $24510 \pm 95$ & 10.9 \\
\hline & Cont. & $59422 \pm 2349$ & 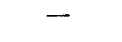 & $46742 \pm 620$ & - & $27501 \pm 1914$ & \\
\hline \multirow[t]{8}{*}{3} & $60 \%$ & $25579 \pm 1155$ & 30.2 & $13317 \pm 1338$ & 62.5 & $33778 \pm 480$ & -16.5 \\
\hline & $40 \%$ & $23316 \pm 1992$ & 36.4 & $13206 \pm 475$ & 62.8 & $29421 \pm 2536$ & -1.4 \\
\hline & $20 \%$ & $40745 \pm 534$ & -11.1 & $15066 \pm 356$ & 57.6 & $26345 \pm 1233$ & 9.3 \\
\hline & Cont. & $36663 \pm 1415$ & - & $35528 \pm 535$ & & $29003 \pm 2384$ & - \\
\hline & $60 \%$ & $25640 \pm 2239$ & 26.6 & $7110 \pm 352$ & 78.0 & $29425 \pm 258$ & 7.1 \\
\hline & $40 \%$ & $25621 \pm 263$ & 26.7 & $12357 \pm 525$ & 61.8 & $31381 \pm 1512$ & 1.0 \\
\hline & 2096 & $32420 \pm 1918$ & 7.1 & $16729 \pm 493$ & 48.3 & $26955 \pm 2103$ & 15.0 \\
\hline & Cont. & $34935 \pm 1507$ & - & $32332 \pm 878$ & - & $31704 \pm 3020$ & - \\
\hline
\end{tabular}

Mean士s.E.M.

Cont.: normal rabbit serum +complement.

while the response to PWM remained essentially unaltered.

\section{Inhibition of $M L C$ response by anti-BAT serum and complement}

The effect of lymphocytes treated with anti-BAT serum and complement on the ability of these lymphocytes to act as a responder and stimulator in the MLC reaction was examined. One way MLC, where cells from one donor (responding cells) were mixed with cells (stimulating cells) from an allogenic donor that had been blocked with mitomycin C, was performed. The results obtained with treatment of responding or stimulating lymphocytes with various concentrations expressed by the cytotoxic titer of anti-BAT serum and complement, are shown in Fig. 5. Treatment of the responding cells resulted in a marked decrease in the ability of these cells to react to stimulating cells. When untreated responding cells were mixed with stimulating cells treated with anti-BAT and complement, the stimulating cells were unaffected by the anti-BAT serum, although a slight decrease in counts was noted at a high concentration (60\% killing).

Effect of anti-BAT serum and complement on blastogenesis and MIF production by sensitized lymphocytes

Lymphocytes from PPD and n-DNA sensitized donors were treated with various concentrations of anti-BAT serum and complement. The PPD sensitized lymphocytes were obtained from normal individuals and the n-DNA sensitized cells from patients with active SLE. The blastogenic response to PPD and n-DNA was expressed in terms of the uptake of ${ }^{3} \mathrm{H}$-thymidine and MIF production by the 


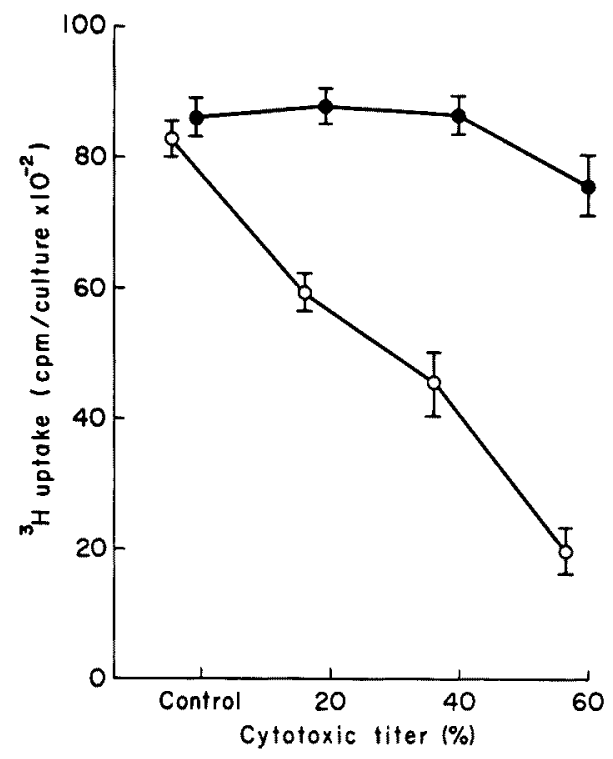

Fig. 5. The effect of lymphocytes treated with anti-BAT serum and complement on the ability of these lymphocytes to act as responder $(0-0)$ and stimulator $(\bullet-\bullet)$ in MLC reaction. Anti-BAT serum was diluted to kill the indicated percentage of peripheral blood lymphocytes in the presence of rabbit complement. Values were expressed as the mean \pm s.E. on triplicate samples from 4 experiments. Control lymphocytes were treated with normal rabbit serum and complement.

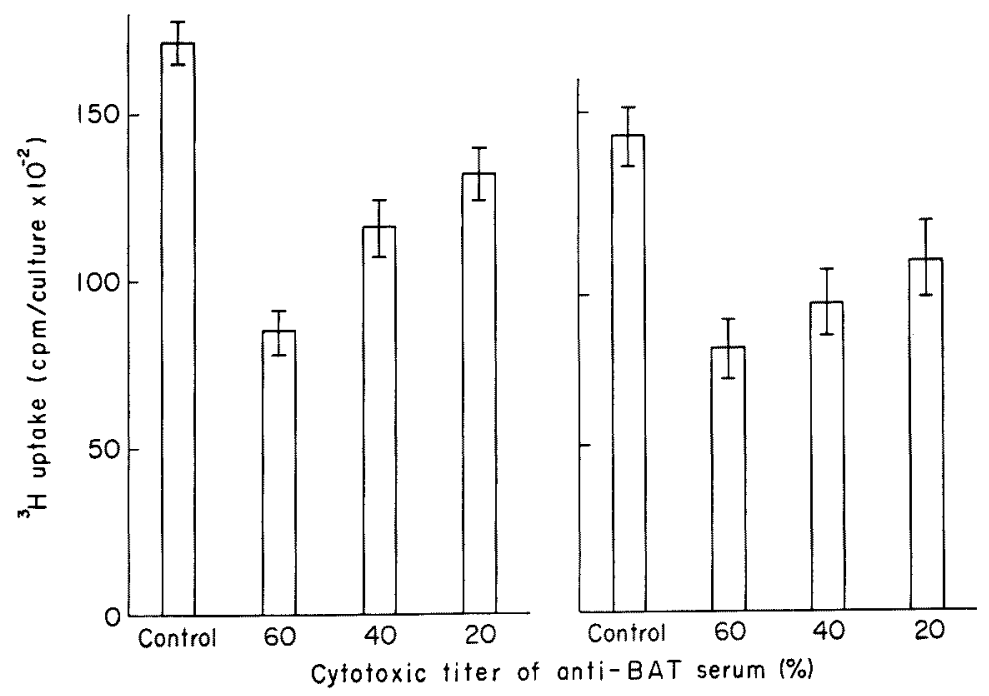

Fig. 6. The effect of treatment of antigen sensitive cells with anti-BAT serum and complement on blastogenic response as measured by the uptake of ${ }^{3} \mathrm{H}$ thymidine. PPD sensitized lymphocytes (left panel) were obtained from normal individuals and n-DNA sensitized cells (right panel) from patients with active SLE. 
TABLE 2. The response of sensitized cells after treatment with anti-BAT serum $+C$ to the stimulation with $P P D$ and $n D N A$ as measured by the MIF production

\begin{tabular}{|c|c|c|c|c|c|c|}
\hline & \multicolumn{3}{|c|}{ PPD $(10 \mu \mathrm{g} / \mathrm{ml})$} & \multicolumn{3}{|c|}{$\mathrm{nDNA}(10 \mu \mathrm{g} / \mathrm{ml})$} \\
\hline & Exp. 1 & 2 & 3 & 4 & 5 & 6 \\
\hline Control & $15.7 \% \dagger$ & $38.9 \%$ & 20.196 & $66.1 \%$ & $66.7 \%$ & $61.0 \%$ \\
\hline $60 \%$ killing* & 8.5 & 15.3 & 14.5 & 70.9 & 48.8 & 69.1 \\
\hline $40 \%$ killing & 13.7 & 39.5 & 24.1 & 72.6 & 64.5 & 73.1 \\
\hline $20 \%$ killing & 23.8 & 43.0 & 22.5 & 59.3 & 71.8 & 69.2 \\
\hline
\end{tabular}

* Cytotoxic titer of antiBAT serum.

$\uparrow \%$ migration.

Control: normal rabbit serum + complement.

Cells from PPD-sensitive donors and nDNA-sensitive donors (active SLE) were treated with antiBAT serum and complement before exposure to PPD or nDNA. Percentage migration less than $75.0 \%$ for PPD and $84.3 \%$ for nDNA was considered to be positive MI test.

MI test. Significant PPD and n-DNA induced blastogenesis was noted with untreated lymphocytes in the presence of PPD or n-DNA (Fig. 6, Table 2). Treatment of these lymphocytes with anti-BAT serum and complement inhibited the response of sensitized lymphocytes. In order to examine the MIF production by these cells, the culture supernatant was assayed for MIF. Neither treatment with anti-BAT serum nor with normal rabbit serum and complement inhibited the production of MIF by these sensitized lymphocytes.

Effect on PWM-driven Ig synthesis of responding lymphocytes by Con A stimulated lymphocytes with anti-BAT serum treatment

Lymphocytes from normal donors were treated with various concentrations of anti-BAT serum and complement. Such treated lymphocytes were cultured with Con A for $48 \mathrm{hr}$ during the first culture period. After washing these cells 3 times, they were added to freshly prepared lymphocytes which were stimulated by PWM in a second assay system. As shown in Table 3, Con A-induced suppressor function was abolished by anti-BAT serum treatment even at a low concentration. This result indicates that anti-BAT serum and complement treatment eliminated part of the Con A reactive lymphocytes with suppressor function.

\section{Effect of anti-BAT on lymphocyte function from patients with active SLE}

The effect of anti-BAT and complement on the activity of lymphocytes to respond to various non-specific mitogens was examined. As shown in Table 4, the ability of anti-BAT treated lymphocytes of active SLE to respond to Con A remained unaltered even at a high concentration of anti-BAT serum. The response of the lymphocytes to PHA-M was slightly affected, like the case of normal lymphocytes, and the response to PWM was essentially unaltered.

These results indicate that there is a decrease in number of the anti-BAT sensitive subset of lymphocytes at the active stage of SLE and this decreased 
TaBLE 3. Effect on PWM-driven Ig synthesis of responding cells by anti BAT-pretreated and ConA stimulated cells

\begin{tabular}{|c|c|c|c|c|}
\hline \multirow{2}{*}{$\begin{array}{l}\text { Responding } \\
\text { cells }\end{array}$} & \multicolumn{2}{|c|}{$\begin{array}{l}\text { Co cultured cells } \\
\text { activated with }\end{array}$} & \multirow{2}{*}{$\begin{array}{l}{ }^{14} \mathrm{C} \text { uptake } \\
\text { (cpm/culture) }\end{array}$} & \multirow{2}{*}{ \%Suppression } \\
\hline & ConA & $\begin{array}{l}\text { Anti BAT serum } \\
\text { (cytotoxic titer) }\end{array}$ & & \\
\hline $1 \times 10^{6}$ & + & $60 \%$ & $12784 \pm 1067$ & -20.4 \\
\hline $1 \times 10^{6}$ & - & & $10622 \pm 135$ & \\
\hline $1 \times 10^{6}$ & + & $40 \%$ & $10031 \pm \quad 26$ & -10.5 \\
\hline $1 \times 10^{6}$ & - & & $9081 \pm 46$ & \\
\hline $1 \times 10^{6}$ & + & $20 \%$ & $7762 \pm 81$ & +14.8 \\
\hline $1 \times 10^{6}$ & - & & $9112 \pm \quad 55$ & \\
\hline $1 \times 10^{6}$ & + & Control & $4326 \pm 47$ & +57.4 \\
\hline $1 \times 10^{6}$ & - & & $10149 \pm 33$ & \\
\hline
\end{tabular}

Mean士s.E.M.

${ }^{14} \mathrm{C}$ uptake cpm represents the mean of duplicate samples \pm s.E.M. from 4 experiments. Lymphocytes were treated with various concentrations of antiBAT serum and complement. Such treated cells were stimulated with Con A during a first culture period: the suppressor activity of these cell preparations was tested by adding them to freshly prepared homologous lymphocytes which were being stimulated by $\mathrm{PMW}$ in a second assay systems.

Control: normal rabbit serum + complement.

TABLE 4. The effect of anti-BAT serum on lymphocyte function of active SLE

\begin{tabular}{ccccccc}
\hline \multirow{2}{*}{$\begin{array}{c}\text { Cytotoxic } \\
\text { titer }\end{array}$} & \multicolumn{3}{c}{$\left({ }^{3} \mathrm{H}\right)$ TdR incorporation in response to mitogen } \\
stimulated with \\
\cline { 2 - 7 }
\end{tabular}

Cont: $\mathrm{AB}$ serum + rabbit complement.

Lymphocytes from 4 patients with active SLE were studied in this experiments.

number of anti-BAT sensitive lymphocytes appears to represent Con A reactive lymphocytes.

\section{Discussion}

Recently, various authors have described the preparation of specific anti-human T cell antisera (Yata et al. 1970; Smith et al. 1973) and reported the functional properties of these sera (Aiuti and Wigzell 1973a, b; Worth et al. 1973). Our results have provided evidence for the sharing of common antigenic structures between $T$ lymphocytes and brain tissues. Although the production of antisera to thymocytes by immunizing rabbits with brain is accepted in mice, the production of anti-human $\mathrm{T}$ lymphocyte sera by immunizing rabbits with human brain has remained 
controversial (Thiele et al. 1973; Brown and Greaves 1974; Schlesinger and Galili 1974). Brouet and Toben (1976) obtained hetero-antiserum to human brain which reacted with only a subset of $\mathrm{T}$ lymphocytes that included $5 \%$ of tonsil T lymphocytes, $23 \%$ of peripheral blood lymphocytes and no thymocytes. Our antiserum, however, killed $100 \%$ of thymocytes at dilutions of between 1:2 and $1: 4$. These conflicting data may be explained in terms of the age of the fetal brain used for immunization, and the different immunizing methods. Brouet and Toben (1976) employed human fetal brain obtained at 21 weeks of gestation, while we immunzied rabbits with fetal brain obtained at 28 weeks of gestation. Since it has been found that Thy antigen is absent in the neonate brain of mice (Thiele et al. 1973), but increases in concentration in a sigmoidal manner with age, a 7 -week difference may be critical for the development of Thy antigen in humans.

Brown and Greaves (1974) also obtained specific anti-T cell serum from rabbits immunized with human brain. All thymus lymphocytes and $60-80 \%$ of peripheral blood lymphocytes were reactive with this serum. The plateau shown by the reacting cells was slightly different from our cytotoxicity curve; however, this may be due to the fact that they used a more sensitive immunofluorescence procedure.

The blastogenic response of cells treated with anti-BAT serum alone indicates that the serum is strongly mitogenic for $T$ lymphocytes. The specificity of this serum for $\mathrm{T}$ lymphocytes was further confirmed by inhibition studies on spontaneous SRBC rosette formation in lymphocytes pretreated with anti-BAT serum.

In our case, the inhibition was observed in the absence of complement similar to the anti-human thymocyte serum reported by Woody et al. (1975). This is in contrast to certain previous anti-brain sera which prevented E-rosette formation in the presence of complement. Stratton and Byfield (1977) reported that antihuman brain serum inbibited spontaneous rosette formation but it required the addition of fresh or even heated normal serum. This indicates that the rosette inhibition was not a complement-dependent phenomenon and may have resulted from direct blocking of rosette receptor sites.

The responses of cells treated with anti-BAT serum and complement to mitogens suggest that Con A responsive cells are the most sensitive. PHA sensitive cells were slightly affected at a higher concentration, while PWM responsive cells were not affected. These results are consistent with the observations of Huntley et al. (1977) and Stratton and Byfield (1977). In this respect, the fact that $\mathrm{T}$ cells containing larger amounts of surface theta antigen are more sensitive to Con $A$, as shown by Granger and Kolb (1968) in mice, appears reasonable.

In the MLC reaction, responding cells are sensitive to anti-BAT serum, while stimulating cells are insensitive to this serum. Anti-BAT serum also inhibits the blastogeneic response of antigen sensitive lymphocytes, whereas the release of MIF from the same cells remains unaffected.

Previous studies have shown that pretreatment of normal lymphocytes with Con $A$ results in the development of suppressor cells which suppress the immuno- 
logical function of other cells (Morimoto 1978; Morimoto et al. 1979).

We used this system to evaluate the effect of anti-BAT serum on Con A-induced suppressor cell function. Con A-induced suppressor function was abolished by anti-BAT treatment even at a low concentration, indicating that the anti-BAT serum eliminated part of the Con A reactive lymphocytes with suppressor function.

We have been investigating the immunological reactivity in patients with SLE and have shown that active SLE patients display a loss of suppressor T lymphocyte function (Morimoto et al. 1977, 1979; Morimoto 1978). and the number of Con $\mathrm{A}$ reactive $\mathrm{T}$ lymphocytes is decreased especially in the active stage. The identification of specific antibodies to the subsets of Con A reactive lymphocytes represents our main interest. In this respect, it is interesting to note that the ability of anti-BAT treated lymphocytes from active SLE to respond to Con A was unaltered even at a high concentration of anti-BAT. These results indicate that Con $\mathrm{A}$ reactive $\mathrm{T}$ cells have a high density of $\mathrm{BAT}$ antigen and there is a decreased number of anti-BAT sensitive $\mathrm{T}$ cells at the active stage of SLE.

In conclusion, it can be said that anti-BAT serum may prove important in the isolation and characterization of suppressor cells in human SLE and may lead to significant advance in our understanding of the pathogenesis and treatment of this disease. Further investigations are needed to elucidate this serum by comparison with the anti-lymphocyte antibody appearing in active SLE.

\section{References}

1) Aiuti, F. \& Wigzell, H. (1973a) Function and distribution pattern of human T lymphocytes. I. Production of anti-T lymphocytes specific sera as estimated by cytotoxicity and elimination of function of lymphocytes. Clin. exp. Immunol., 13, 171-181.

2) Aiuti, F. \& Wigzell, H. (1973b) Function and distribution pattern of human T lymphocytes. II. Presence of T lymphocytes in normal humans and in humans with various immunodeficiency disorders. Clin. exp. Immunol., 13, 183-189.

3) Barker, A.D., Rheins, M.S. \& St-Pierre, R.L. (1973) The effect of rabbit anti-mouse brain associated theta serum on the immunologic responsiveness of AKR mice. Cell Immunol., 7, 85-91.

4) Brouet, J.C. \& Toben, H. (1976) Characterization of subpopulation of human T lymphocytes reactive with a heteroantiserum to human brain. J. Immunol., 116, 1041-1044.

5) Brown, G. \& Greaves, M.F. (1974) Cell surface markers for human T and B lymphocytes. Eur. J. Immunol., 4, 302-310.

6) David, J.R. \& Scholssman, S.F. (1968) Immunochemical studies on the specificity of cellular hypersensitivity. $J$. exp. Med., 128, 1451-1459.

7) Golub, E.S. (1971) Brain associated theta antigen: Reactivity of rabbit anti-mouse brain with mouse lymphoid cells. Cell Immunol., 2, 353-361.

8) Granger, G.A. \& Kolb, W.P. (1968) Lymphocyte in vitro cytotoxicity: mechanism of immune and non-immune small lymphocyte mediated target cell destruction. $J$. Immunol., 101, 111-120.

9) Huntley, A.C., Fletcher, M.P., Ikeda, R.M. \& Gershwin, M.E. (1977) Shared antigenic determinants between rabbit antihuman brain and rabbit antihuman thymocyte sera: Relationship to the lymphocytotoxic antibodies of systemic lupus erythematosus. Clin Immunol. Immunopathol., 7, 269-280. 
10) Jondal, M., Holm, G. \& Wigzell, H. (1972) Surface marker on human T and B lymphocytes. J. exp. Med., 136, 207-215.

11) Kongshaven, P.A., Gold, P., Shuster, J., Colquhoun, B. \& Freedman, S.0. (1974) Ability of anti-brain heteroantisera to distinguish thymus-derived lymphocytes in various species. Clin. Immunol. Immunopathol., 3, 1-15.

12) Morimoto, C. (1978) Loss of suppressor T lymphocytes function in patients with SLE. Clin. exp. Immunol.. 32, 125-183.

13) Morimoto, C., Abe, T. \& Homma, M. (1979) Altered function of suppressor T lymphocytes in patients with active SLE. Clin Immunol. Immunopathol., 13, 161170 .

14) Morimoto, C., Abe, T., Hara, M. \& Homma, M. (1977) In vitro TNP-specific antibody formation by peripheral lymphocytes in patients with SLE. Scand. J. Immunol., 6, $575-579$.

15) Schlesinger, M. \& Galili, U. (1974) Antigenic difference between T and B lymphocytes in man. Isr. J. med. Sci., 10, 7M5-724.

16) Smith, R.W., Terry, W.D., Buell, D.N. \& Sell, K.W. (1973) An antigenic marker for human thymic lymphocytes. $J$. Immunol., 110, 884-887.

17) Stratton, J.A. \& Byfield, P.E. (1977) Reaction of anti-human brain serum with human lymphocyte subpopulation. Cell Immunol., 28, 1-14.

18) Thiele, H.G., Stark, R., Keeser, D. \& Zeimpel, H. (1973) Lack of antigenic correlations between brain and thymus. Lancet, 2, 1447.

19) Thor, D.E., Jureziz, R.E. \& Veach, S.R. (1968) Cell migration inhibition factor released by antigen from human peripheral lymphocytes. Nature, 219, 755-757.

20) Woody, J.N., Ahmed, A., Knudsen, R.C., Strong, D.M. \& Sell, K.W. (1975) Human T cell heterogeneity as delineated with a specific human thymus lymphocytes antiserum. J. clin. Invest., 55, 956-966.

21) Worth, H.H., Cooper, A.G. \& Brown, M.L. (1973) Inhibition of human lymphocyte rosetting by anti-T sera. Nature, 243, 109-111.

22) Yata, J., Klein, G., Kobayashi, N., Furukawa, T. \& Yanagisawa, M. (1970) Human thymus lymphoid tissue antigen and its presence in leukemia and lymphoma. Clin. exp. Immunol., 7, 781-792. 